\title{
EVALUATION OF QUANTITATIVE AND QUALITATIVE TRAITS OF WILD ECOTYPES OF FORAGE GRASSES
}

\author{
MIRIAM KIZEKOVÁ*, JANKA MARTINCOVÁ, L’UBICA JANČOVÁ
}

Plant Production Research Center Piešt’any

\begin{abstract}
KIZEKOVÁ, M. - MARTINCOVÁ, J. - JANČOVÁ, L.: Evaluation of quantitative and qualitative traits of wild ecotypes of forage grasses. Agriculture (Pol’nohospodárstvo), vol. 59, 2013, no. 1, pp. 21-32.
\end{abstract}

Wild ecotypes of Festuca rubra L. (four accessions), Poa pratensis L. (three accessions ) and Phleum pratense L. (three accessions) originating from Central Slovakia were investigated. Dry matter production, qualitative traits as well as mineral content were studied under identical soilclimatic conditions in a three-cut system. Yield potential of wild ecotypes of Festuca rubra L. coming from mountain regions was significantly lower $(P<0.01)$ when compared to Festuca rubra L. cultivar Levočská. In contrast, as a consequence of low variability, the dry matter yield of Phleum pratense L. wild ecotypes originating from high- er altitudes was comparable to the dry matter yields of Festuca rubra L. cultivar Levočská. There were not noted any considerable differences found in the content of crude protein, fibre or mineral substances between the wild ecotypes and the cultivars. All accessions showed consistent patterns in seasonal distribution with the highest dry matter yield at the first cut and with the lowest one at the third cut. In general, concentration of crude protein and fibre did not vary considerably among cultivars and wild ecotypes at all species under uniform growing conditions.

Key words: wild ecotypes; Festuca rubra L.; Poa pratensis L.; Phleum pratense L.; dry matter yield; mineral content

As crop improvement through plant breeding critically depends on crop genetic resources, knowledge of potential of natural populations is an essential starting point. Detections of qualitative and production traits of wild populations originating from various environmental conditions can identify the strength and the weakness of these populations and indicate a possibility to use them for breeding new improved varieties. Moreover, evaluation of indigenous wild genetic resources improves a basis of information on their specific characteristics and contributes to sustainable use of domestic natural resources.

Improved fodder quality and adaptation to changing climate has been recognized as important goals for breeding of fodder grasses (Wilkins \& Humphreys, 2003). Crude protein and fibre has been recognised as critical parameters of nutritive value (Bonesmo \& Bèlanger, 2002). Besides these important parameters influencing the amount of energy for maintenance and performance of ruminants, an increasing interest in the content of mineral nutrients is well documented (Steinshamn et al. 2004; Fulkerson et al. 2007). It is useful for plant breeders, conventional and organic farmers as well, to know the range of mineral concentration. Those genotypes that utilize soil nutrients more efficiently are of value to livestock producers who depend on forages to meet the energy and nutrient requirements of livestock. Genetic variation of mineral elements within the grass species has been studied in tall fescue (Sleper et al. 1977; Reeder et al. 1986), orchard grass (Míka 1982; Stratton \& Sleper 1979).

In Slovakia, grassland management and environmental conditions affect utilisation of grass species and consequently their breeding. The Slovak culti-

Ing. Miriam Kizeková, PhD. (*Corresponding author), Ing. Janka Martincová, PhD., Ing. L'ubica Jančová, Plant Production Research Center Piešt’any - Grassland and Mountain Agriculture Research Institute Banská Bystrica, 97421 Banská Bystrica, Mládežnícka 36, Slovak Republic. E-mail:kizekova@vutphp.sk 
vars of fodder grasses were developed from the plant material originating from the Czech Republic (Phlem pratense L. cultivar Levočská, Festuca rubra L. cultivar Levočská) or from Slovakia (Poa pratensis L. cultivar Lea). Phleum pratense L. is naturally found at lowland hay meadows in Slovakia (Viceníková \& Polák 2003). However it is the most productive under cool and humid conditions of mountain and upland regions (Jančovič et al. 2005).

Festuca rubra L. is found from wet to dry soil conditions with exception to very dry soils. It tolerates short-term drought and short-term wet soil conditions as well. Festuca rubra L. is most frequently found in long-term or permanent meadows and pastures with low and medium level of fertilisation.

Poa pratensis L. is hardy, persistent and attractive grass adapted to a wide range of environmental conditions with very good forage quality. It can colonize the gaps in the sward and its re-growth rate is very fast, so it produces a very thick sward. Along with Festuca rubra L., it is one of the best grasses for mountain regions (Peeters 2004).

Although assessment of nutritive value and nutrient content of monocultures of grass species grown in Slovakia has been reported (Hanzes et al. 2005), only few studies have evaluated the nutritive value and nutrient content of wild ecotypes of fodder grasses (Martincová 2009).

The aim of the presented research was to assess dry matter production, qualitative traits and content of mineral nutrients of Festuca rubra L., Poa pratensis L. and Phleum pratense L. accessions originating from the Central Slovakia.

\section{MATERIAL AND METHODS}

The initial material for the study comprised three accessions of Festuca rubra L., two accessions of Poa pratensis L. and two accessions of Phleum pratense L. (Table 1). All ecotype populations were collected in Central Slovakia in 2001. Altitudes of the sites ranged from 214 to $1533 \mathrm{~m}$ a.s.1. The "Hontianske Nemce" site was located in the southern part of the Central Slovakia and the other sites ("Nižná Boca", Liptovská Lužná", "Hel'pa", "Čierny Balog", "Čertovica") were located in the Low Tatras mountains range. Within each species the following cultivars were used as the controls: Festuca rubra L. cv. Levočská, Poa pratensis L. cv. Lea and Phleum pratense $\mathrm{L}$. cv. Levočská. These cultivars were obtained from the "Plant Breeding Station Levočské Lúky" in Slovakia.

In 2004, the research trial was established at the site of Grassland and Mountain Agriculture Research Institute in Banská Bystrica $\left(48^{\circ} 39^{\prime} \mathrm{N}\right.$, $19^{\circ} 08^{\prime} \mathrm{E}$ ) altitude $420 \mathrm{~m}$ a.s.l. on sandy loam soil with higher content of gravel and rich in plant-available minerals.

At the site the mean annual rainfall is $795.5 \mathrm{~mm}$ and mean annual temperature is $8.1^{\circ} \mathrm{C}$ (data recorded by the Department of Meteorological Service in Banská Bystrica). In 2005, the total annual rainfall and the sum of rainfall over growing season were 856 and $403 \mathrm{~mm}$, respectively. Mean annual and seasonal temperatures did not show any particular difference from average values. By contrast, the year 2006 was a dry ones. Rainfall during growing season was $35 \%$ lower than the long-term average seasonal precipitation. The months of June, July and September were particularly dry. Compared to long-term monthly averages, the sum of rainfall during June $(92.8 \mathrm{~mm})$, July (80.9 mm), September $(55.0 \mathrm{~mm})$ were lower by 39,68 and $90 \%$, respectively.

The trial was arranged in a randomized complete block design with two replications. Precultivated plants were planted in the experimental plots $(2 \times 0.5 \mathrm{~m}$ size $)$. Plant spacing was $500 \times 250$ $\mathrm{mm}$. The fertiliser rates were applied as follows: $60 \mathrm{~kg} / \mathrm{ha}$ of nitrogen was split into two dressings (65\% in spring and $35 \%$ after the first cut), $70 \mathrm{~kg} \mathrm{P}_{2} \mathrm{O}_{5} /$ ha and $100 \mathrm{~kg} \mathrm{~K} 2 /$ ha was applied in spring. Plants were cut three times a year: the first cut at the ear emergence; the second cut - approximately 6 to 8 weeks later; the third cut approximately 8 to 10 weeks after the second cut.

The dry mater (DM) yield was determined by drying to a constant weight at $60^{\circ} \mathrm{C}$ in an electric drier. The crude protein (CP) was determined by the Kjeldahl method $(\mathrm{N} \times 6.25)$. Phosphorus $(\mathrm{P})$ analysis was carried out colorimetrically using a Skalar autoanalyzer. The determination of potassium (K) and calcium $(\mathrm{Ca})$ was carried out using flame photometer FLAPHO 4 and that of magnesium $(\mathrm{Mg})$ determination was carried out by atomic absorp- 
$\mathrm{T}$ a

Site information for the accessions of ecotypes of Festuca rubra L., Poa pratensis L. and Phleum pratense L. used in the field trial. Temperature $(\mathrm{T})$ and rainfall $(\mathrm{R})$ represent values of annual long-term averages (source:

Slovak Hydrometeorological Institute). Accession designation responds to the Genebank Piešt'any code for collected material (SVK NTAT 01-454 i.e. acronym of the collecting expedition in the Slovakia to the Low Tatras Mountains and year - collecting number)

\begin{tabular}{|c|c|c|c|c|}
\hline $\begin{array}{l}\text { Wild ecotype collection site } \\
\text { /cultivar }\end{array}$ & $\begin{array}{l}\text { Accession designation } \\
\text { /information on cultivar }\end{array}$ & $\begin{array}{l}\text { Site altitude } \\
\text { (m a.s.1.) }\end{array}$ & $\begin{array}{c}\mathrm{T} \\
{\left[{ }^{\circ} \mathrm{C}\right]}\end{array}$ & $\begin{array}{c}\mathrm{R} \\
{[\mathrm{mm}]}\end{array}$ \\
\hline \multicolumn{5}{|l|}{ Festuca rubra L. } \\
\hline Liptovská Lužná & SVK NTAT 01-454 & 880 & 4.8 & 950 \\
\hline Hel'pa & SVK NTAT 01-371 & 799 & 4.7 & 850 \\
\hline Nižná Boca & SVK NTAT 01-198 & 892 & 4.1 & 967 \\
\hline Levočská & forage cultivar, registered in 1949 & - & - & - \\
\hline \multicolumn{5}{|l|}{ Poa pratensis L. } \\
\hline Hontianske Nemce & SVK & 214 & 8.2 & 592 \\
\hline Čierny Balog & SVK & 550 & 6.6 & 758 \\
\hline Lea & turf cultivar, registered in 2000 & - & - & - \\
\hline \multicolumn{5}{|l|}{ Phleum pratense $\mathrm{L}}$. \\
\hline Čertovica & SVK NTAT 01-433 & 1533 & 3.9 & 1,086 \\
\hline Nižná Boca & SVK NTAT 01-193 & 892 & 4.1 & 967 \\
\hline Levočská & forage cultivar, registered in 1950 & - & - & - \\
\hline
\end{tabular}

\section{$\mathrm{T} \quad \mathrm{a} \quad \mathrm{b} \quad 1 \quad \mathrm{e} \quad 2$}

Total dry mater (DM) yield and mean content of $\mathrm{CP}$, fibre, $\mathrm{P}, \mathrm{K}, \mathrm{Ca}, \mathrm{Mg}$ and the ratios of $\mathrm{Ca} / \mathrm{P}$ and $\mathrm{K} /(\mathrm{Ca}+\mathrm{Mg})$ in Festuca rubra $\mathrm{L}$. accessions

\begin{tabular}{|l|c|r|r|r|r|r|}
\hline \multirow{2}{*}{ Traits } & \multirow{2}{*}{$P$ value } & $\begin{array}{c}\text { Liptovská } \\
\text { Lužná }\end{array}$ & Hel'pa & $\begin{array}{c}\text { Nižná } \\
\text { Boca }\end{array}$ & $\begin{array}{c}\text { Mean } \\
\text { of ecotypes }\end{array}$ & $\begin{array}{c}\text { Cultivar } \\
\text { Levočská }\end{array}$ \\
\cline { 3 - 7 } & & 3.99 & 3.91 & 3.21 & $3.70^{\mathrm{a}}$ & $7.77^{\mathrm{b}}$ \\
$\mathrm{DM}[\mathrm{t} / \mathrm{ha}]$ & $0.004^{++}$ & 141.49 & 166.46 & 156.35 & 154.77 & 134.35 \\
$\mathrm{CP}[\mathrm{g} / \mathrm{kg}]$ & 0.328 & 188.98 & 187.02 & 191.46 & 189.15 & 196.74 \\
Fibre $[\mathrm{g} / \mathrm{kg}]$ & 0.645 & 2.71 & 2.83 & 2.68 & 2.74 & 2.56 \\
$\mathrm{P}[\mathrm{g} / \mathrm{kg}]$ & 0.472 & 21.05 & 22.91 & 21.36 & 21.77 & 21.22 \\
$\mathrm{~K}[\mathrm{~g} / \mathrm{kg}]$ & 0.669 & 7.81 & 8.25 & 8.35 & 8.14 & 8.96 \\
$\mathrm{Ca}[\mathrm{g} / \mathrm{kg}]$ & 0.661 & 2.79 & 2.92 & 3.14 & 2.95 & 4.05 \\
$\mathrm{Mg}[\mathrm{g} / \mathrm{kg}]$ & 0.182 & 2.99 & 2.97 & 3.24 & 3.07 & 3.48 \\
$\mathrm{Ca} / \mathrm{P}$ & 0.590 & 2.27 & 2.33 & 2.24 & 2.28 & 2.24 \\
$\mathrm{~K} /(\mathrm{Ca}+\mathrm{Mg})$ & 0.932 & $0.01)$ &
\end{tabular}

${ }^{++}$Significant $(P<0.01)$ differences between mean of ecotypes and cultivar Levočská 
tion spectrophotometer GBC 908AA. The ratios of $\mathrm{P} / \mathrm{Ca}$ and $\mathrm{K} /(\mathrm{Ca}+\mathrm{Mg})$ were calculated.

Dry mater yield and nutrient concentrations were subjected to analysis of variance followed by post hoc comparison using the Tukey's HSD test (Statit). Analysis of variance was performed for the research years 2005 and 2006 .

\section{RESULTS}

Festuca rubra L.

Four accessions of Festuca rubra L. were evaluated. Mean values of quantitative and qualitative parameters are given in Table 2. The total DM production of wild ecotypes ranged from 3.21 (Nižná

$\mathrm{T}$ a $\quad \mathrm{b} \quad 1$ e 3

Dry mater (DM) yield, the content of CP, fibre, $\mathrm{P}, \mathrm{K}, \mathrm{Ca}, \mathrm{Mg}$ and the ratios of $\mathrm{Ca} / \mathrm{P}$ and $\mathrm{K} /(\mathrm{Ca}+\mathrm{Mg})$ in Festuca rubra L. accessions in the $1^{\text {st }}, 2^{\text {nd }}$ and $3^{\text {rd }}$ cuts

\begin{tabular}{|c|c|c|c|c|c|c|}
\hline \multirow[b]{2}{*}{ Traits } & \multirow[b]{2}{*}{$P$ value } & \multicolumn{5}{|c|}{ Accession } \\
\hline & & $\begin{array}{l}\text { Liptovská } \\
\text { Lužná }\end{array}$ & Hel'pa & Nižná Boca & $\begin{array}{l}\text { Mean of } \\
\text { ecotypes }\end{array}$ & $\begin{array}{l}\text { Cultivar } \\
\text { Levočská }\end{array}$ \\
\hline \multicolumn{7}{|c|}{$1^{\text {st }}$ cut } \\
\hline $\mathrm{DM}[\mathrm{t} / \mathrm{ha}]$ & $0.001^{++}$ & 2.30 & 2.30 & 1.84 & $2.15^{\mathrm{a}}$ & $4.19^{b}$ \\
\hline $\mathrm{CP}[\mathrm{g} / \mathrm{kg}]$ & 0.095 & 91.80 & 118.88 & 107.70 & 106.13 & 85.50 \\
\hline Fibre $[\mathrm{g} / \mathrm{kg}]$ & 0.226 & 232.42 & 227.20 & 211.74 & 223.79 & 145.38 \\
\hline $\mathrm{P}[\mathrm{g} / \mathrm{kg}]$ & 0.936 & 2.24 & 2.49 & 2.38 & 2.37 & 2.39 \\
\hline $\mathrm{K}[\mathrm{g} / \mathrm{kg}]$ & 0.824 & 18.03 & 21.05 & 20.39 & 19.82 & 19.41 \\
\hline $\mathrm{Ca}[\mathrm{g} / \mathrm{kg}]$ & 0.880 & 4.07 & 3.99 & 3.99 & 4.21 & 4.12 \\
\hline $\mathrm{Mg}[\mathrm{g} / \mathrm{kg}]$ & 0.360 & 1.73 & 1.72 & 1.72 & 1.83 & 1.56 \\
\hline $\mathrm{Ca} / \mathrm{P}$ & 0.368 & 1.88 & 1.90 & 1.69 & 1.83 & 1.74 \\
\hline $\mathrm{K} /(\mathrm{Ca}+\mathrm{Mg})$ & 0.781 & 3.17 & 3.32 & 3.57 & 3.35 & 3.53 \\
\hline \multicolumn{7}{|c|}{$2^{\text {nd }} \mathrm{cut}$} \\
\hline $\mathrm{DM}[\mathrm{t} / \mathrm{ha}]$ & 0.269 & 1.00 & 0.92 & 0.86 & 0.93 & 1.53 \\
\hline $\mathrm{CP}[\mathrm{g} / \mathrm{kg}]$ & 0.550 & 180.19 & 204.21 & 188.30 & 190.90 & 179.92 \\
\hline Fibre $[\mathrm{g} / \mathrm{kg}]$ & 0.940 & 176.10 & 189.47 & 199.98 & 190.90 & 187.72 \\
\hline$P[g / k g]$ & 0.616 & 3.02 & 3.01 & 2.85 & 2.96 & 2.80 \\
\hline $\mathrm{K}[\mathrm{g} / \mathrm{kg}]$ & 0.793 & 24.10 & 23.54 & 21.71 & 23.12 & 22.34 \\
\hline $\mathrm{Ca}[\mathrm{g} / \mathrm{kg}]$ & 0.273 & 9.83 & 10.17 & 10.86 & 10.29 & 13.28 \\
\hline $\operatorname{Mg}[\mathrm{g} / \mathrm{kg}]$ & 0.100 & 3.42 & 3.34 & 3.91 & 3.56 & 6.47 \\
\hline $\mathrm{Ca} / \mathrm{P}$ & 0.256 & 3.29 & 3.43 & 3.95 & 3.56 & 4.61 \\
\hline $\mathrm{K} /(\mathrm{Ca}+\mathrm{Mg})$ & 0.460 & 1.87 & 1.78 & 1.51 & 1.72 & 1.37 \\
\hline \multicolumn{7}{|c|}{$3^{\text {rd }}$ cut } \\
\hline DM [t/ha] & 0.133 & 0.68 & 0.70 & 0.51 & 0.63 & 1.33 \\
\hline $\mathrm{CP}[\mathrm{g} / \mathrm{kg}]$ & 0.272 & 152.46 & 176.29 & 173.05 & 167.27 & 137.63 \\
\hline Fibre $[\mathrm{g} / \mathrm{kg}]$ & 0.830 & 158.44 & 144.39 & 162.67 & 155.16 & 157.12 \\
\hline $\mathrm{P}[\mathrm{g} / \mathrm{kg}]$ & 0.510 & 2.86 & 2.99 & 2.82 & 2.89 & 2.50 \\
\hline $\mathrm{K}[\mathrm{g} / \mathrm{kg}]$ & 0.737 & 21.03 & 24.16 & 21.97 & 22.39 & 21.91 \\
\hline $\mathrm{Ca}[\mathrm{g} / \mathrm{kg}]$ & 0.873 & 9.53 & 9.59 & 10.21 & 9.91 & 9.48 \\
\hline $\mathrm{Mg}[\mathrm{g} / \mathrm{kg}]$ & 0.480 & 3.23 & 3.40 & 3.80 & 3.48 & 4.13 \\
\hline $\mathrm{Ca} / \mathrm{P}$ & 0.873 & 3.81 & 3.57 & 4.08 & 3.82 & 4.10 \\
\hline $\mathrm{K} /(\mathrm{Ca}+\mathrm{Mg})$ & 0.907 & 1.77 & 1.89 & 1.64 & 1.77 & 1.82 \\
\hline
\end{tabular}

${ }^{++}$Significant $(P<0.01)$ differences between mean of ecotypes and cultivar Levočská 
Boca site) to 3.99 t/ha (Liptovská Lužná site). Cultivar Levočská showed the highest production potential in comparison with the wild ecotype accessions (7.77 t/ha of DM; $P=0.004)$. In the first cut, there was the significant difference in the mean DM production between the wild ecotypes and the cultivar (Table 3). In the second and the third cut, the highest DM production was recorded at the cultivar Levočská, nevertheless, the differences between the wild ecotypes and the cultivar were not significant.

The higher mean content of $\mathrm{CP}$ was recorded at the wild ecotypes than at cultivar Levočská (Table 2). In the fist cut, CP content ranged from 85.50 to $118.88 \mathrm{~g} / \mathrm{kg}$ both in the cultivar Levočská and the wild ecotype from Helpa site (Table 3). For all accessions, the highest content of $\mathrm{CP}$ was observed in the second cut. Among the wild ecotype accessions, the lowest $\mathrm{CP}$ content was found at the wild ecotype from Liptovská Lužná site in all the cuts.

At fibre content the opposite trend was observed. The highest mean content of fibre was recorded at cultivar Levočská $(196.74 \mathrm{~g} / \mathrm{kg})$ and the lowest one in the wild ecotype from Hel'pa site $(187.02 \mathrm{~g} / \mathrm{kg})$. Only in the second cut, the fibre content was lower in cultivar Levočská comparing to the mean values at the wild ecotype accessions (Table 3).
As to the content of minerals, it did not show any significant differences between the wild ecotypes and the cultivar. The mean content of $\mathrm{P}$ and $\mathrm{K}$ was higher in wild ecotypes than in the cultivar (Table 2). In the first cut, the lowest content of $P$ and $\mathrm{K}$ was found at the wild ecotype from Liptovská Lužná site (Table 5). In the second and third cut, the lowest content of $\mathrm{P}$ was recorded in cultivar Levočská.

The lowest mean content of $\mathrm{Ca}$ and $\mathrm{Mg}$ had the wild ecotype from Liptovská Lužná site (Table 2). Except for the first cut, the cultivar Levočská showed the highest content of $\mathrm{P}$ and $\mathrm{Mg}$ in comparison to the wild ecotypes. The highest $\mathrm{Ca} / \mathrm{P}$ ratio was found at cultivar Levočská, resulting from the highest mean $\mathrm{Ca}$. On the other hand, higher mean values of $\mathrm{K} /(\mathrm{Ca}+\mathrm{Mg})$ ratio were recorded in the wild ecotype accessions (Table 2).

\section{Poa pratensis $\mathrm{L}$.}

Two wild ecotypes of Poa pratensis L. showed a contrast in DM yield, where the wild ecotype from the low-land Hontianske Nemce site reached significantly higher DM yield (4.74 t/ha) than the second other one from the mountainous site of Čierny Ba$\log (3.85 \mathrm{t} / \mathrm{ha})$. The distribution of DM yield to the cuts was similar for all accessions, with the highest

T a b 1 e 4

Total dry mater (DM) yield and the mean content of $\mathrm{CP}$, fibre, $\mathrm{P}, \mathrm{K}, \mathrm{Ca}, \mathrm{Mg}$ and the ratios of $\mathrm{Ca} / \mathrm{P}$ and $\mathrm{K} /(\mathrm{Ca}+\mathrm{Mg})$ in Poa praensis L. accessions

\begin{tabular}{|l|c|c|c|r|r|}
\hline \multirow{2}{*}{ Traits } & \multirow{2}{*}{$P$ value } & \multicolumn{4}{|c|}{ Accession } \\
\cline { 3 - 6 } & & $\begin{array}{c}\text { Hontianske } \\
\text { Nemce }\end{array}$ & Čierny Balogh & Mean of ecotypes & Cultivar Lea \\
\hline $\mathrm{DM}[\mathrm{t} / \mathrm{ha}]$ & 0.663 & 4.74 & 3.85 & 4.29 & 4.49 \\
$\mathrm{CP}[\mathrm{g} / \mathrm{kg}]$ & 0.988 & 160.12 & 166.80 & 163.46 & 163.11 \\
Fibre $[\mathrm{g} / \mathrm{kg}]$ & 0.724 & 226.47 & 196.34 & 211.41 & 204.54 \\
$\mathrm{P}[\mathrm{g} / \mathrm{kg}]$ & 0.473 & 2.63 & 2.69 & 2.66 & 2.85 \\
$\mathrm{~K}[\mathrm{~g} / \mathrm{kg}]$ & 0.587 & 23.54 & 21.95 & 22.74 & 7.84 \\
$\mathrm{Ca}[\mathrm{g} / \mathrm{kg}]$ & 0.515 & 7.98 & 7.71 & 3.04 & 6.79 \\
$\mathrm{Mg}[\mathrm{g} / \mathrm{kg}]$ & 0.607 & 2.91 & 3.17 & 3.11 & 2.78 \\
$\mathrm{Ca} / \mathrm{P}$ & 0.476 & 3.23 & 2.99 & 2.42 & 2.52 \\
$\mathrm{~K} /(\mathrm{Ca}+\mathrm{Mg})$ & 0.775 & 2.38 & 2.45 & & 2.55 \\
\hline
\end{tabular}


yield in the first cut and the lowest in the third one. In the first and the second cut, the highest DM production was observed in the ecotype from Hontianske Nemce site, whereas in the third cut the significantly higher DM yield was recorded at the cultivar Lea (Table 5).
Qualitative traits were better at the wild ecotype from the mountainous Čierny Balog site. The lowest mean CP content and the highest mean content of fibre were found in the wild ecotype from the lowland Hontianske Nemce site (Table 4). The highest

T a b 1 e 5

Dry mater (DM) yield, the content of $\mathrm{CP}$, fibre, $\mathrm{P}, \mathrm{K}, \mathrm{Ca}, \mathrm{Mg}$ and the ratios of $\mathrm{Ca} / \mathrm{P}$ and $\mathrm{K} /(\mathrm{Ca}+\mathrm{Mg})$ in Poa pratensis L. accessions in the 1st, 2nd and 3rd cuts

\begin{tabular}{|c|c|c|c|c|c|}
\hline \multirow[b]{2}{*}{ Traits } & \multirow[b]{2}{*}{$P$ value } & \multicolumn{4}{|c|}{ Accession } \\
\hline & & $\begin{array}{l}\text { Hontianske } \\
\text { Nemce }\end{array}$ & Čierny Balog & Mean of ecotypes & Cultivar Lea \\
\hline \multicolumn{6}{|c|}{$1^{\text {st }}$ cut } \\
\hline $\mathrm{DM}[\mathrm{t} / \mathrm{ha}]$ & 0.414 & 2.63 & 2.54 & 2.59 & 2.42 \\
\hline $\mathrm{CP}[\mathrm{g} / \mathrm{kg}]$ & 0.643 & 107.72 & 107.68 & 107.70 & 99.54 \\
\hline Fibre $[\mathrm{g} / \mathrm{kg}]$ & 0.735 & 267.60 & 226.28 & 246.94 & 238.48 \\
\hline$P[g / k g]$ & 0.670 & 2.46 & 2.54 & 2.50 & 2.67 \\
\hline $\mathrm{K}[\mathrm{g} / \mathrm{kg}]$ & 0.283 & 21.20 & 20.97 & 21.09 & 18.98 \\
\hline $\mathrm{Ca}[\mathrm{g} / \mathrm{kg}]$ & 0.540 & 4.71 & 3.85 & 4.28 & 3.81 \\
\hline $\mathrm{Mg}[\mathrm{g} / \mathrm{kg}]$ & 0.380 & 2.06 & 1.79 & 1.93 & 1.68 \\
\hline $\mathrm{Ca} / \mathrm{P}$ & 0.570 & 1.92 & 1.56 & 1.74 & 1.46 \\
\hline $\mathrm{K} /(\mathrm{Ca}+\mathrm{Mg})$ & 0.960 & 3.14 & 3.84 & 3.46 & 3.47 \\
\hline \multicolumn{6}{|c|}{$2^{\text {nd }} \mathrm{cut}$} \\
\hline $\mathrm{DM}[\mathrm{t} / \mathrm{ha}]$ & 0.959 & 1.35 & 0.78 & 1.06 & 1.04 \\
\hline $\mathrm{CP}[\mathrm{g} / \mathrm{kg}]$ & 0.455 & 194.65 & 212.10 & 203.38 & 219.25 \\
\hline Fibre $[\mathrm{g} / \mathrm{kg}]$ & 0.336 & 210.11 & 203.59 & 206.25 & 197.29 \\
\hline$P[g / k g]$ & 0.190 & 2.75 & 2.87 & 2.81 & 3.14 \\
\hline $\mathrm{K}[\mathrm{g} / \mathrm{kg}]$ & 0.335 & 24.33 & 22.47 & 23.40 & 25.38 \\
\hline $\mathrm{Ca}[\mathrm{g} / \mathrm{kg}]$ & 0.242 & 9.48 & 10.28 & 9.88 & 8.63 \\
\hline $\mathrm{Mg}[\mathrm{g} / \mathrm{kg}]$ & 0.644 & 3.33 & 4.26 & 3.79 & 3.46 \\
\hline $\mathrm{Ca} / \mathrm{P}$ & $0.008^{++}$ & 3.45 & 3.58 & $3.52^{\mathrm{b}}$ & $2.74^{\mathrm{a}}$ \\
\hline $\mathrm{K} /(\mathrm{Ca}+\mathrm{Mg})$ & 0.149 & 1.91 & 1.54 & 1.73 & 2.12 \\
\hline \multicolumn{6}{|c|}{$3^{\text {rd }}$ cut } \\
\hline $\mathrm{DM}$ [t/ha ] & $0.049^{+}$ & 0.76 & 0.54 & $0.65^{\mathrm{a}}$ & $1.02^{\mathrm{b}}$ \\
\hline $\mathrm{CP}[\mathrm{g} / \mathrm{kg}]$ & 0.539 & 177.98 & 180.62 & 179.30 & 170.53 \\
\hline Fibre $[\mathrm{g} / \mathrm{kg}]$ & 0.948 & 201.71 & 159.15 & 180.43 & 177.86 \\
\hline $\mathrm{P}[\mathrm{g} / \mathrm{kg}]$ & 0.922 & 2.69 & 2.66 & 2.67 & 2.75 \\
\hline $\mathrm{K}[\mathrm{g} / \mathrm{kg}]$ & 0.369 & 25.07 & 22.40 & 23.74 & 21.65 \\
\hline $\mathrm{Ca}[\mathrm{g} / \mathrm{kg}]$ & 0.659 & 9.75 & 9.00 & 9.37 & 7.94 \\
\hline $\mathrm{Mg}[\mathrm{g} / \mathrm{kg}]$ & 0.762 & 3.35 & 3.47 & 3.41 & 3.19 \\
\hline $\mathrm{Ca} / \mathrm{P}$ & 0.748 & 4.32 & 3.82 & 4.07 & 3.32 \\
\hline $\mathrm{K} /(\mathrm{Ca}+\mathrm{Mg})$ & 0.969 & 2.10 & 1.97 & 2.03 & 2.06 \\
\hline
\end{tabular}

+ Significant $(P<0.05)$ differences between mean of ecotypes and cultivar Lea

${ }^{++}$Significant $(P<0.01)$ differences between mean of ecotypes and cultivar Lea 
content of CP was recorded at cultivar Lea the in the second cut $(219.25 \mathrm{~g} / \mathrm{kg})$.

The content of minerals did not show any significant differences between the wild ecotypes and the cultivar. Mean content of P ranged from 2.63 (wild ecotype Hontianske Nemce site) to $2.85 \mathrm{~g} / \mathrm{kg}$ (cultivar Lea). The highest content of $\mathrm{P}$ was observed at cultivar Lea in all the cuts, when compared to the wild ecotypes. As to the content of $\mathrm{K}$, there was variability found at the wild ecotypes and the cultivar in all the cuts. In the second cut, the $\mathrm{K}$ content was lower at the wild ecotypes, whereas in the first and the third cut the lowest content of $\mathrm{K}$ was recorded in cultivar Lea (Table 5). The content of $\mathrm{Ca}$ and $\mathrm{Mg}$ was higher in both the wild ecotypes than in cultivar Lea at all the cuts. The mean value of $\mathrm{Ca} / \mathrm{P}$ ratio ranged from 2.52 at cultivar Lea to 3.23 at the wild ecotype from Hontianske Nemce site. In the second cut, cultivar Lea showed significantly lower value of $\mathrm{Ca} / \mathrm{P}$ ratio comparing to the mean value found for the wild ecotypes (Table 5). By contrast, the mean values of $\mathrm{K} /(\mathrm{Ca}+\mathrm{Mg})$ were lower at the wild ecotypes than those at the cultivar Lea (Table 4).

\section{Phleum pratense $\mathrm{L}$.}

There were differences in DM production between the two ecotypes and the cultivar of Phleum pratense L. ranging from 4.82 (wild ecotype, Nižná
Boca site) to $5.25 \mathrm{t} / \mathrm{ha}$ at cultivar Levočská. In the first cut, the highest DM yield was recorded at the wild ecotype from Čertovica site. In the second and the third cut, cultivar Levočská showed higher DM production in comparison to wild ecotypes (Table 7).

Similarly to the situation with Festuca rubra L. and Poa pratensis L., any significant variability of the qualitative parameters and the content of minerals was not found in the ecotypes of Phleum pratense L. (Table 6).

The wild ecotypes showed better qualitative traits than those found in cultivar Levočská. The highest CP content was found at the wild ecotype from Čertovica site in the second cut (Table 7). The lowest content of fibre was recorded at all the accessions in the third cut.

Mean content of P ranged from 2.41 (cultivar Levočská) to $2.62 \mathrm{~g} / \mathrm{kg}$ (wild ecotype Čertovica site). The wild ecotype from Čertovica site showed the highest mean content of all mineral nutrients when compared to the wild ecotype from Nižná Boca site and cultivar Levočská (Table 6). Contrary to that, the wild ecotype from Nižná Boca site showed the lowest mean content of $\mathrm{Ca}$ and $\mathrm{Mg}$. Subsequently, this manifested in the lowest mean values of $\mathrm{Ca} / \mathrm{P}$ and $\mathrm{K} /(\mathrm{Ca}+\mathrm{Mg})$ ratios at the wild ecotype from Nižná Boca site as well.

T $\quad \begin{array}{llllllllll} & \mathrm{b} & 1 & \mathrm{e} & 6\end{array}$

Total dry mater (DM) yield, the mean content of $\mathrm{CP}$, fibre, $\mathrm{P}, \mathrm{K}, \mathrm{Ca}, \mathrm{Mg}$ and the ratios of $\mathrm{Ca} / \mathrm{P}$ and $\mathrm{K} /(\mathrm{Ca}+\mathrm{Mg})$ in Phleum pratense L. accessions

\begin{tabular}{|c|c|c|c|c|c|}
\hline \multirow[b]{2}{*}{ Traits } & \multirow[b]{2}{*}{$P$ value } & \multicolumn{4}{|c|}{ Accession } \\
\hline & & Čertovica & Nižná Boca & $\begin{array}{l}\text { Mean of } \\
\text { ecotypes }\end{array}$ & $\begin{array}{l}\text { Cultivar } \\
\text { Levočská }\end{array}$ \\
\hline $\mathrm{DM}[\mathrm{t} / \mathrm{ha}]$ & 0.900 & 5.22 & 4.82 & 5.02 & 5.25 \\
\hline $\mathrm{CP}[\mathrm{g} / \mathrm{kg}]$ & 0.684 & 144.83 & 144.61 & 144.72 & 136.53 \\
\hline Fibre $[\mathrm{g} / \mathrm{kg}]$ & 0.287 & 182.89 & 176.90 & 179.89 & 197.40 \\
\hline$P[g / k g]$ & 0.203 & 2.62 & 2.59 & 2.61 & 2.41 \\
\hline $\mathrm{K}[\mathrm{g} / \mathrm{kg}]$ & 0.694 & 23.30 & 23.03 & 23.16 & 22.48 \\
\hline $\mathrm{Ca}[\mathrm{g} / \mathrm{kg}]$ & 0.924 & 7.92 & 7.38 & 7.55 & 7.81 \\
\hline $\mathrm{Mg}[\mathrm{g} / \mathrm{kg}]$ & 0.928 & 3.58 & 3.09 & 3.34 & 3.40 \\
\hline $\mathrm{Ca} / \mathrm{P}$ & 0.675 & 3.04 & 2.94 & 2.99 & 3.31 \\
\hline $\mathrm{K} /(\mathrm{Ca}+\mathrm{Mg})$ & 0.966 & 2.49 & 2.46 & 2.47 & 2.50 \\
\hline
\end{tabular}




\section{DISCUSSION}

According to Cristea et al. (2010), DM yield of a cultivar of Festuca rubra L. grown as monoculture varied according to nitrogen fertilisation and it ranged from $2.82 \mathrm{t} / \mathrm{ha}$ for untreated control up to $4.31 \mathrm{t} / \mathrm{ha}$ for the rate of $100 \mathrm{~kg} / \mathrm{ha}$. Similar studies conducted with several alternative grasses in Austria showed that DM yield of monocultures of cultivar Festuca rubra L. were $12.3 \mathrm{t} / \mathrm{ha}$ and $13.6 \mathrm{t} / \mathrm{ha}$, respectively (Grais et al. 2011). Dürr et al. (2005) observed differences in yield potential of Poa pratensis L. cultivars between two sites in Canada. The DM yields of Poa pratensis L. cultivar grown under

$\mathrm{T}$ a $\quad \mathrm{b} \quad 1$ e 7

Dry mater (DM) yield, the content of CP, fibre, $\mathrm{P}, \mathrm{K}, \mathrm{Ca}, \mathrm{Mg}$ and the ratios of $\mathrm{Ca} / \mathrm{P}$ and $\mathrm{K} /(\mathrm{Ca}+\mathrm{Mg})$ in Phleum pratense L. accessions in the $1^{\text {st }}, 2^{\text {nd }}$ and $3^{\text {rd }}$ cuts

\begin{tabular}{|c|c|c|c|c|c|}
\hline \multirow{2}{*}{ Traits } & \multirow{2}{*}{$P$ value } & \multicolumn{4}{|c|}{ Accession } \\
\hline & & Čertovica & Nižná Boca & Mean of ecotypes & Cultivar Levočská \\
\hline \multicolumn{6}{|c|}{$1^{\text {st }}$ cut } \\
\hline $\mathrm{DM}[\mathrm{t} / \mathrm{ha}]$ & 0.974 & 3.99 & 3.67 & 3.83 & 3.79 \\
\hline $\mathrm{CP}[\mathrm{g} / \mathrm{kg}]$ & 0.373 & 102.83 & 117.96 & 110.41 & 97.15 \\
\hline Fibre $[\mathrm{g} / \mathrm{kg}]$ & 0.231 & 211.47 & 202.15 & 206.81 & 235.63 \\
\hline$P[g / k g]$ & 0.531 & 2.62 & 2.74 & 2.68 & 2.47 \\
\hline $\mathrm{K}[\mathrm{g} / \mathrm{kg}]$ & 0.979 & 25.14 & 24.29 & 24.71 & 24.59 \\
\hline $\mathrm{Ca}[\mathrm{g} / \mathrm{kg}]$ & 0.797 & 4.61 & 4.45 & 4.53 & 2.39 \\
\hline $\operatorname{Mg}[\mathrm{g} / \mathrm{kg}]$ & 0.675 & 2.09 & 1.98 & 2.03 & 1.88 \\
\hline $\mathrm{Ca} / \mathrm{P}$ & 0.761 & 1.76 & 1.65 & 1.71 & 1.80 \\
\hline $\mathrm{K} /(\mathrm{Ca}+\mathrm{Mg})$ & 0.942 & 4.00 & 3.77 & 3.88 & 3.96 \\
\hline \multicolumn{6}{|c|}{$2^{\text {nd }}$ cut } \\
\hline $\mathrm{DM}[\mathrm{t} / \mathrm{ha}]$ & 0.472 & 0.70 & 0.52 & 0.61 & 0.85 \\
\hline $\mathrm{CP}[\mathrm{g} / \mathrm{kg}]$ & 0.849 & 177.00 & 173.33 & 175.17 & 167.97 \\
\hline Fibre $[\mathrm{g} / \mathrm{kg}]$ & 0.347 & 186.08 & 174.37 & 180.23 & 199.29 \\
\hline$P[g / k g]$ & 0.128 & 2.65 & 2.88 & 2.76 & 2.53 \\
\hline $\mathrm{K}[\mathrm{g} / \mathrm{kg}]$ & 0.243 & 22.33 & 23.47 & 23.05 & 20.53 \\
\hline $\mathrm{Ca}[\mathrm{g} / \mathrm{kg}]$ & 0.708 & 9.80 & 9.16 & 9.48 & 10.75 \\
\hline $\operatorname{Mg}[\mathrm{g} / \mathrm{kg}]$ & 0.714 & 4.57 & 2.94 & 3.75 & 4.27 \\
\hline $\mathrm{Ca} / \mathrm{P}$ & 0.521 & 3.65 & 3.18 & 3.42 & 4.30 \\
\hline $\mathrm{K} /(\mathrm{Ca}+\mathrm{Mg})$ & 0.559 & 1.79 & 1.96 & 1.88 & 1.53 \\
\hline \multicolumn{6}{|c|}{$3^{\text {rd }}$ cut } \\
\hline $\mathrm{DM}[\mathrm{t} / \mathrm{ha}]$ & 0.859 & 0.53 & 0.65 & 0.59 & 0.64 \\
\hline $\mathrm{CP}[\mathrm{g} / \mathrm{kg}]$ & 0.881 & 154.63 & 142.52 & 148.57 & 144.47 \\
\hline Fibre $[\mathrm{g} / \mathrm{kg}]$ & 0.526 & 151.13 & 154.16 & 152.65 & 157.28 \\
\hline$P[g / k g]$ & 0.615 & 2.59 & 2.17 & 2.38 & 2.23 \\
\hline $\mathrm{K}[\mathrm{g} / \mathrm{kg}]$ & 0.839 & 22.43 & 21.03 & 21.73 & 22.30 \\
\hline $\mathrm{Ca}[\mathrm{g} / \mathrm{kg}]$ & 0.774 & 9.36 & 8.53 & 8.95 & 8.29 \\
\hline $\mathrm{Mg}[\mathrm{g} / \mathrm{kg}]$ & 0.871 & 4.10 & 4.36 & 4.23 & 4.06 \\
\hline $\mathrm{Ca} / \mathrm{P}$ & 0.988 & 3.72 & 3.98 & 3.85 & 3.83 \\
\hline $\mathrm{K} /(\mathrm{Ca}+\mathrm{Mg})$ & 0.388 & 1.67 & 1.64 & 1.65 & 2.00 \\
\hline
\end{tabular}


warm and dry conditions in Normandin site ranged from 4.16 to $4.54 \mathrm{t} / \mathrm{ha}$, whereas Poa pratensis L. cultivars grown in Charlottetown sites with better soil and climate conditions yielded from 7.70 to $10.10 \mathrm{t} / \mathrm{ha}$. To the contrary Grais et al. (2011) reported higher DM yields at Poa pratensis L. under drier conditions (13.0 t/ha) comparing to humid conditions ( $8.8 \mathrm{t} / \mathrm{ha})$. Relatively lower DM yield at Festuca rubra L. and Poa pratensis L. observed in this study was associated with abiotic stress caused by the drought during the growing season in 2006. For Phleum pratense L., as reported by Bertrand et al. (2008), higher day and night temperatures resulted in low DM yield $(5.41 \mathrm{t} / \mathrm{ha})$ comparing to cooler temperature regime with long photoperiod. Low DM yield of all accessions of Phleum pratense $\mathrm{L}$. in this study are consistent with findings of Jančovič et al. (2005) who noted that timothy (Phleum pratense L.) is not suitable to dry and warm conditions.

We found that yield potential of wild ecotypes differed within each grass species. The DM yield of wild ecotypes of Festuca rubra L. originating from mountain regions with low temperatures was significantly lower when compared to Festuca rubra L. cultivar Levočská. By contrast, yield production of the wild ecotypes of Phleum pratense L. was comparable with that of its cultivar. Similarly, Lemežiene and Kanapeckas (2008) found that the wild ecotypes of timothy differed in production only negligibly. As the cultivar Levočská of Phleum pratense L. was developed from the wild ecotypes coming from the Czech Republic where climate is more humid and with higher temperatures during winter comparing to Slovakia, the wild ecotypes originating from higher altitude of Central Slovakia with lower mean annual temperature seem to be adaptive to unfavourable weather conditions during winter season.

Wild ecotype of Poa pratensis L. originating from Hontianske Nemce - the site in the south of Central Slovakia with higher mean annual temperature and lower precipitation - showed significantly higher DM yield comparing to the wild ecotype originating from the humid conditions at Čierny Balog site. These results are consistent with findings of Weißhuhn et al. (2011) who reported that native perennial grassland plant species of the British provenance with the lower precipitation showed the weakest response to drought, whereas those of
Swiss provenance with the higher summer precipitation showed the strongest response.

At all accessions, DM yield was affected by the growing season of the year. The DM yield decreased significantly from the first cut to the third one (not shown). We found that cultivars gave higher DM yield in the third cut comparing to wild ecotypes. However, each species differed in DM production in the first and the second cut. Whereas Festuca rubra L. cv. Levočská was superior in DM yield comparing to the wild ecotypes in all the cuts, the wild ecotype of Poa pratensis L. originating from Hontianske Nemce site in the south of Central Slovakia, showed the highest DM production in the first and the second cut. By contrast, Phleum pratense L. did not show any clear difference in DM production between cultivars and wild ecotypes at the cuts. Similar seasonal distribution of DM yield among wild ecotypes and cultivar within each species (Festuca rubra L., Poa pratensis L. and Phleum pratense L.) indicated that the wild ecotypes were dependent on the environmental conditions at the same degree as the cultivars.

In general, the content of $\mathrm{CP}$ and fibre did not vary considerably among cultivars and wild ecotypes at all species. In accordance with our results, Bovolenta et al. (2008) found only limited variation in mean $\mathrm{CP}$ content at eight grass species of alpine pastures. The highest $\mathrm{CP}$ content was recorded in Poa pratensis L., comparing to Festuca rubra L. and Phleum pratense L. Similarly, Dürr et al. (2005) found Poa pratensis L. as having the highest total $\mathrm{N}$ content. In our study, the mean CP content was 144.72 and $136.53 \mathrm{~g} / \mathrm{kg}$ in the wild ecotypes and the cultivar of Phleum pratense L., respectively, which contrasts to Nordheim-Viken et al. (2009) who reported that Phleum pratense L. is rich in CP. Nevertheless, Kunelius et al. (2003) found differences in the CP content between early and late grazed cultivars of Phleum pratense L., where the content of $\mathrm{CP}$ was lower in the late grazed cultivars than in the early ones.

For all grass species, there were not any differences in mean nutrient content between wild ecotypes and cultivars. Our results are consistent with Dürr et al. (2005) who did not find any clear distinction among cultivars for being "high" or "low" in minerals. Similarly, mean values of $\mathrm{Ca} / \mathrm{P}$ and 
$\mathrm{K} /(\mathrm{Ca}+\mathrm{Mg})$ ratio did not show any significant differences between the wild ecotypes and the cultivars.

It is well established that forages mineral profiles varies with the harvest during growing season (Whitehead 2000; Pelletier et al. 2008). For all accessions, the content of $\mathrm{Ca}$ and $\mathrm{Mg}$ increased as a season advances towards the autumn. Our findings are in agreement with Poland and Manske (2004) who reported that mineral concentrations in coolseason grasses were significantly influenced by advancing season. According to Hopkins et al. (1994) changes in the content of $\mathrm{Ca}$ and $\mathrm{Mg}$ in forage could be a consequence of differential uptake associated with seasonal factors such as temperature, water availability and light intensity. Seasonal variation in K concentration showed difference among Festuca rubra L., Poa pratensis L. and Phleum pratense L. At Festuca rubra L. and Poa pratensis L. the lowest content of $\mathrm{K}$ was found in the first cut, whereas $\mathrm{K}$ concentration in Phleum pratense L. non- significantly decreased with advancing growing season. Similarly Cherney and Cherney (1997) reported that the $\mathrm{K}$ content of Phleum pratense $\mathrm{L}$. is lower in its regrowth. The differences among the species should be explained by a very high environmental effect and large genotype $\times$ environmental interactions for the K concentration (Sleper et al. 1989). Nevertheless, mineral profiles at the cuts did not show differences between the cultivars and the wild ecotypes within the species. These results are consistent with the results of Míka (1982) who did not found variability in $\mathrm{Ca}$ and $\mathrm{K}$ concentration among twelve cultivars of Dactylis glomerata L. under uniform soil and environmental conditions.

Seasonal changes in mineral concentrations in all accessions resulted in variation of $\mathrm{Ca} / \mathrm{P}$ and $\mathrm{K} /(\mathrm{Ca}+\mathrm{Mg})$ ratios during the growing season. Wild ecotypes of Festuca rubra and Phleum pratense L. obtained higher concentration of $\mathrm{P}$ in the cuts what resulted in lower $\mathrm{Ca} / \mathrm{P}$ ratio in comparison to the cultivars. By contrast, cultivar Lea of Poa pratensis L. accumulated more P during the growing season comparing to the wild ecotypes and had significantly lower $\mathrm{Ca} / \mathrm{P}$ ratio in the second cut.

The highest $\mathrm{K} /(\mathrm{Ca}+\mathrm{Mg})$ ratio was observed for all accessions in the first cut, where wild ecotypes of Festuca rubra L. showed lower values in com- parison to Festuca rubra L. cultivar Levočská and the other accessions of Poa pratensis L. and Phleum pratense $\mathrm{L}$. as well. With advancing season, the increasing content of $\mathrm{Ca}$ and $\mathrm{Mg}$ in the wild ecotypes and the cultivars of Festuca rubra L., Poa pratensis L. and Phleum pratense L. resulted in $\mathrm{K} /(\mathrm{Ca}$ $+\mathrm{Mg}$ ) ratio decreasing to the value recommended for cattle diets (Whitehead 2000). These results are consistent with those of Pelletier et al. (2007) who reported that $\mathrm{Ca}$ and $\mathrm{Mg}$ concentrations have a great impact on the $\mathrm{K} /(\mathrm{Ca}+\mathrm{Mg})$ ratio of Phleum pratense $\mathrm{L}$. and the higher concentration of $\mathrm{Ca}$ and $\mathrm{Mg}$ in timothy harvested in summer resulted in reduced $\mathrm{K} /(\mathrm{Ca}+\mathrm{Mg})$ ratio when compared with timothy harvested in spring. The differences in $\mathrm{K} /(\mathrm{Ca}+\mathrm{Mg})$ ratio between the wild ecotypes and the cultivars of all the grass species were not statistically significant, but the ratio was higher at the wild ecotypes of Festuca rubra L. and Phleum pratense L. than at the cultivars.

The yield potential of Poa pratensis L. wild ecotype (from Hontianske Nemce site at the south of Central Slovakia) and the wild ecotypes of Phleum pratense L. (from the higher altitude sites of Central Slovakia) seems interesting for a future breeding programme aimed at upland environmental conditions of Central Slovakia. However, it was found that the cultivar Levočská of Festuca rubra L. showed significantly higher DM yield than the wild ecotypes, probably due to its genetic improvement.

As a consequence of uniform soil and environmental conditions, there were no considerable differences in the content of CP or mineral profiles between the wild ecotypes and the cultivars within the species.

\section{CONCLUSIONS}

The results of our study showed that the wild ecotypes Festuca rubra L., Poa pratensis L. and Phleum pratense L. differed from each other in their yield potential. While the DM yield of Festuca rubra L. cultivar Levočská was superior to that of Festuca rubra L. wild ecotypes, the wild ecotypes of Phleum pratense L., originating from the higher altitude sites provided the DM yields comparable to those recorded with Phleum pratense L. cultivar 
Levočská. Nevertheless, all the ecotype accessions showed consistent patterns in the seasonal distribution of DM yield. Analyses of qualitative traits and mineral content confirmed limited genetic variability among wild ecotypes and cultivars within the species under uniform environmental conditions.

Acknowledgement. This research work was funded by the research program of the Ministry of Agriculture of the Slovak Republic No. 2005 UO 270500203 „Measures for mitigating and adapting to climate change in grassland management and field crop production".

\section{REFERENCES}

BERTRAND, A. - TREMBLAY, G.F. - PELlETIER, S. - CAStOnguAY, Y. - BÈLANGER, G. 2008. Yield and nutritive value of timothy as affected by temperature, photoperiod and time of harvest. In Grass and Forage Science, vol. 63, 2008, no. 4, pp. $421-432$. DOI: 10.1111/j.1365-2494.2008.00649.x.

BONESMO, H. - BÈLANGER, G. 2002. Timothy yield and nutritive value by the CATIMO model. II. Digestibility and fibre. In Agronomy Journal, vol. 94, 2002, no. 2, pp. 345-350.

BOVOLENTA, S. - SPANGHERO, M. - DOVIER, S. ORLANDI, D. - CLEMENTEL, F. 2008. Chemical composition and net energy content of alpine pasture species during the grazing season. In Animal Feed Science and Technology, vol. 146, 2008, no. 1-2, pp. 178-191.

CHERNEY, J.H. - CHERNEY, D.J.R. 1997. Potassium accumulation in perennial cool-season grass forage. In Proceedings of the XVIII International Grassland Congress. Winnipeg, 1997, pp. 21-22.

CRISTEA, C. - NECULAI, D. - CRISTEA, T. - DRAGOMIR, C. - RECHITEAN, D. - TOTH, S. - FRĂȚILĂ, I. 2010. Influence of some red fescue (Festuca rubra L.) associations and nitrogen-based fertilization on dry matter yield. In Animal Science and Biotechnologies, vol. 43, 2010, no. 2, pp. 140-142.

DÜRR, G.H. - KUNELIUS, H.T. - DRAPEAU, R. MCRAE, K. - FILLMORE, S.A.E. 2005. Herbage yield and composition of Kentucky bluegrass (Poa pratensis L.) cultivars under two harvest systems. In Canadian Journal of Plant Science, vol. 88, 2005, no. 3, pp. 1043-1055.

FULKERSON, W.J. - NEAL, J.S. - CLARK, C.F. - HORADAGORA, A. - NANDRA, K.S. - BARCHIA, I. 2007. Nutritive value of forage species grown in the warm temperate climate of Australia for dairy cows: grasses and legumes. In Livestock Science, vol. 107, 2007, no. $2-3$, pp. 253-264.

GRAIS, W. - KRAUTZER, B. - PŐTSCH, E.M. 2011. Sustainability of alternative grass species for grassland management in Austria under changing climate conditions. In Grassland Science in Europe, vol. 16, 2011, pp. 440-442.

HANZES, L. - BRITAŇÁK, N. - ILAVSKÁ, I. 2005. Production ability of grasses of higher water-soluble carbohydrate content in mountain production area. In Agriculture (Pol'nohospodárstvo), vol. 51, 2005, no. 3, pp. $145-150$.

HOPKINS, A. - ADAMSON, A.H. - BOWLING, P.J. 1994. Response of permanent and reseeded grassland to fertilizer nitrogen. 2. Effects on concentrations of $\mathrm{Ca}, \mathrm{Mg}$, $\mathrm{K}, \mathrm{Na}, \mathrm{S}, \mathrm{P}, \mathrm{Mn}, \mathrm{Zn}, \mathrm{Cu}, \mathrm{Co}$ and $\mathrm{Mo}$ in herbage at a range of sites. In Grass and Forage Science, vol. 49, no. 1, pp. 9-20.

JANČOVIČ, J. - ĎURKOVÁ, E. - VOZÁR, L. 2005. Krmoviny I. Pestovanie polných krmovin [Forage crops I. Field forage crop production.]. Nitra : ÚVTIP, 2005. 100 pp. ISBN 80-89088-40-6

KUNELIUS, H.T. - DÜRR, G.H. - MCRAE, K.B. - FILLMORE, S.A.E. - BÈLANGER, G. - PAPADOPOULOS, Y.A. 2003. Yield, herbage composition and tillering of timothy cultivars under grazing. In Canadian Journal of Plant Science, vol. 83, 2003, pp. 57-63.

LEMEŽIENE, N. - KANAPECKAS, J. 2008. Selection efficiency of wild ecotypes for forage and turf grass breeding. In Biologija, vol. 54, 2008, no. 2, pp. 125-128.

MARTINCOVÁ, J. 2009. Assessment of genetic resources of wild ecotypes and a range of cultivars of grasses and forage legumes. In Grassland Science in Europe, vol. 14, 2009, pp. 531-534.

MÍKA, V. 1982. Sodium, potassium and calcium concentrations in varieties of Dactylis glomerata. In Grass and Forage Science, vol. 37, 1982, no. 4, pp. 321-325. DOI: $10.1111 / \mathrm{j} .1365-2494.1982 . t b 01612 . \mathrm{x}$

NORDHEIM-VIKEN, H. - VOLDEN, H. - JØRGENSEN, M. 2009. Effects of maturity stage, temperature and photoperiods on growth and nutritive value of timothy (Phleum pratense L.). In Animal Feed Science and Technology, vol. 152, 2009, no. 3, pp. 204-218.

PEETERS, A. 2004. Wild and sown grasses. Profiles of a temperate species selection: ecology, biodiversity. Rome : FAO, 2004. 311 pp. ISBN 92-5-105159-3.

PELLETIER, S. - BÈlANGER, G. - TREMBLAY, G.F. - SEGUIN, P. - DRAPEAU, R. - ALLARD, G. 2007. Dietary cation-anion difference of timothy (Phleum pratense L.) as influenced by application of chloride and nitrogen fertilizer. In Grass and Forage Science, vol. 62,2007 , no. 1 , pp. 66-77. DOI: $10.1111 /$ j.13652494.2007.00565.x

PELlETIER, S. - BÈLANGER, G. - TREMBLAY, G.F. - VIRKAJÄRVI, P. - ALLARD, G. 2008. Timothy mineral concentration and derived indices related to cattle metabolic disorders: A review. In Canadian Journal of Plant Science, vol. 88, 2008, pp. 1043-1055.

POLAND, W.W. - MANSKE, L.L. 2004. Effect of year and season on mineral concentrations of cool-and warm season grasses from native range : annual report. North Dakota : DREC, 2004.

REEDER, L.R. JR. - NGUYEN, H.T. - SLEPER, D.A. - BROWN, J.R. 1986. Genetic variability of mineral concentrations in tall fescue grown under controlled 
conditions. In Crop Science, vol. 26, 1986, no. 3, pp. 514-518.

SLEPER, D.A. - VOGEL, K.P. - ASAY, K.H. - MAYLAND, H.F. 1989. Using plant breeding and genetics to overcome the incidence of grass tetany. In Journal of Animal Science, vol. 67, 1989, no. 12, pp. 3456-3462.

SLEPER, D.A. - GARNER, G.B. - ASAY, H. - BOLAND, R. - PICKET, E.E. 1977. Breeding for $\mathrm{Mg}, \mathrm{Ca}, \mathrm{K}$ and P content in tall fescue. In Crop Science, vol. 17, 1977, no. 3, pp. 433-438.

STEINSHAMN, H. - STRØM, T. - GOVASMARK, E. BAKKEN, A.K. - HANSEN, S. 2004. Mineral content of herbage from organically managed grasslands as influenced by yield and botanical composition. In Grassland Science in Europe, vol. 9, 2004, pp. 996-998.

STRATTON, S.D. - SLEPER, D.A. 1979. Genetic variation and interrelationships of several minerals in orchard grass herbage. In Crop Science, vol. 19, 1979, no. 4, pp. $477-481$.
VICENÍKOVÁ, A. - POLÁK, P. 2003. Európsky významné biotopy na Slovensku [Habitats of European Importance in Slovakia.]. Banská Bystrica : ŠOP SR, 2003. $151 \mathrm{pp}$. ISBN 80-89035-24-8.

WEIßHUHN, K. - AUGE, H. - PRATI, D. 2011. Geographic variation in the response to drought in nine grassland species. In Basic and Applied Ecology, vol. 12, 2011, no. 1, pp. 21-28.

WHITEHEAD, D.C. 2000. Nutrient elements in grassland: soil-plant-animal relationships. Wallingford : CABI Publishing, 2000. 369 pp. ISBN 0-85199-437-7

WILKINS, P.W. - HUMPHREYS, M.O. 2003. Progress in breeding forage grasses for temperate agriculture. In Journal of Agronomical Science, vol. 140, 2003, no. 2, pp. $129-150$.

Received: October 29th, 2012 